Article

\title{
Evaluation of the Bactericidal Activity of a Hyaluronic Acid-Vehicled Clarithromycin Antibiotic Mixture by Confocal Laser Scanning Microscopy
}

\author{
Narcisa Mandras ${ }^{1}$, Mario Alovisi ${ }^{2}, * \mathbb{D}$, Janira Roana ${ }^{1}\left(\mathbb{D}\right.$, Paola Crosasso ${ }^{3}$, Anna Luganini ${ }^{4}(\mathbb{D}$, \\ Damiano Pasqualini ${ }^{2}{ }^{\circ}$, Elisa Genta ${ }^{2}{ }^{-}$, Silvia Arpicco ${ }^{5}(0)$, Giuliana Banche ${ }^{1}$, \\ Annamaria Cuffini ${ }^{1}$ and Elio Berutti ${ }^{2}$ \\ 1 Department of Public Health and Pediatrics, University of Turin, 10126 Turin, Italy; \\ narcisa.mandras@unito.it (N.M.); janira.roana@unito.it (J.R.); giuliana.banche@unito.it (G.B.); \\ annamaria.cuffini@unito.it (A.C.) \\ 2 Department of Surgical Sciences, Dental School, Endodontics, University of Turin, 10126 Turin, Italy; \\ damiano.pasqualini@unito.it (D.P.); genta.elisa@gmail.com (E.G.); elio.berutti@unito.it (E.B.) \\ 3 S.C.Farmacia Laboratorio Galenici-Sperimentazioni Cliniche-Farmacovigilanza e Diagnostici, Azienda \\ Ospedaliera Città della Salute e della Scienza, 10126 Turin, Italy; pcrosasso@molinette.piemonte.it \\ 4 Department of Life Sciences and Systems Biology, University of Turin, 10123 Turin, Italy; \\ anna.luganini@unito.it \\ 5 Department of Drug Science and Technology, University of Torino, 10125 Turin, Italy; silvia.arpicco@unito.it \\ * Correspondence: mario.alovisi@unito.it; Tel.: +39-(0)11-6331569; Fax: +39-(0)11-6708389
}

Received: 13 December 2019; Accepted: 16 January 2020; Published: 13 April 2020

Featured Application: Thanks to the use of confocal laser scanning microscopy, it is proved that ciprofloxacin, metronidazole and clarithromycin (3-MIXC) mixed with hyaluronic acid (HA) is a possible alternative to root canal disinfection during regenerative endodontic procedures (REPs) in order to avoid a substantial discoloration of the teeth, mainly due to the chelating effect of the minocycline.

\begin{abstract}
Confocal laser scanning microscopy (CLSM) was used to evaluate the antibacterial effect and depth of action of a novel clarithromycin-containing triple antibiotic mixture, which was proposed for root canal disinfection in dental pulp regeneration. A previous study reported that this mixture had no tooth discoloration effects in vitro. After infection with Enterococcus faecalis for 3 weeks, the dentinal tubules in the cylindrical root specimens were exposed to different antibiotic mixtures: ciprofloxacin, metronidazole and minocycline (3-MIX); ciprofloxacin, metronidazole and clarithromycin (3-MIXC) and ciprofloxacin and metronidazole (2-MIX). Each antibiotic formulation was mixed with macrogol (MG) or hyaluronic acid (HA) vehicles. CLSM and viability staining were used to quantitatively analyze the mean depth of the antibacterial effect and the proportions of dead and live bacteria inside the dentinal tubules. The 3-MIX and 3-MIXC demonstrated a similar depth of action. The mean proportion of dead bacteria was similar in the 3-MIX and 3-MIXC groups, and both were statistically higher than that of 2-MIX $(p=0.014)$. Each antibiotic mixture showed a higher bactericidal efficacy if conveyed with HA, compared to MG (3-MIX, $p=0.019$; 3-MIXC, $p=0.013$ and 2-MIX, $p=0.0125$ ). The depth of action and the antibacterial efficacy of 3-MIXC seemed comparable with 3-MIX.
\end{abstract}

Keywords: confocal laser scanning microscopy; triple antibiotic paste; double antibiotic paste; regenerative endodontic procedures; hyaluronic acid 


\section{Introduction}

Very wide canals, open apexes and thin dentinal walls characterize immature permanent teeth. When pulp necrosis occurs as a result of caries or trauma, root development is arrested. Therefore, root canal debridement and obturation present several clinical difficulties, and teeth are more prone to fracture [1,2]. Apexification protocols with calcium hydroxide or mineral trioxide aggregate (MTA) are effective, but they do not consider the development of the root canal walls $[3,4]$. Therefore, these teeth remain more prone to root fracture and present a lower long-term prognosis [4,5]. Regenerative endodontic procedures (REPs) have been proposed as an alternative treatment approach [6-8]. Replacing cells in the pulpo-dentin complex is advantageous due to the potential for promoting root development and strengthening of the dentinal walls [9]. However, a complete disinfection of the canal space, without mechanical instrumentation, is mandatory to prepare for the ingrowth of vital tissue [10]. Contemporary guidelines suggest the use of calcium hydroxide or different antibiotic mixtures for the disinfection of the root canal during regenerative procedures [11]. Several in vitro and in vivo studies have described the efficacy of the combination of ciprofloxacin, metronidazole and minocycline (3-MIX), against several endodontic pathogens [12-15]. However, this topical triple antibiotic paste (TAP) may result in substantial tooth discoloration, primarily due to the chelating effect of the minocycline against the calcium ions [16-18]. Additionally, the bonding agents applied in the pulp chamber may be partially ineffective against root and crown staining $[19,20]$. For this reason, calcium hydroxide and a double antibiotic paste (DAP) were preferably proposed [21]. However, calcium hydroxide could present a weakening effect on the thin dentine walls [22]. Moreover, the alternative use of a DAP containing ciprofloxacin and metronidazole and without minocycline (2-MIX) has proven less effective at the same concentration [23,24]. A recent study [25] reported that between 1 and $5 \mathrm{mg} / \mathrm{mL}$ DAP provided a significant, direct antibacterial effect against bacterial biofilm obtained from immature teeth with necrotic pulps, but only $5 \mathrm{mg} / \mathrm{mL}$ DAP showed substantial residual antibacterial effects against bacterial biofilms. Therefore, the recovery of a novel disinfecting solution is current in the emergent pulp regeneration field. Previous studies have reported that clindamycin or cefaclor-modified TAPs have demonstrated favorable outcomes when they were used during regenerative endodontic treatments [17]. However, an alternative antibiotic combination, composed of ciprofloxacin, metronidazole and clarithromycin (3-MIXC), has demonstrated high antimicrobial properties with no discoloration effects in vitro [26]. Clarithromycin is an advanced-generation macrolide with a wide spectrum of activity and excellent inflammatory-dependent activity, both intra and extracellular [27-29].

In addition, the application of hyaluronic acid (HA) has been described in a variety of different uses in several medical settings [30]. HA is a biodegradable polymer, consisting of N-acetyl-D-glucosamine and beta-glucoronic acid. The gel is well-tolerated, safe and effective. The viscoelastic nature of $\mathrm{HA}$ and its biocompatibility and non-immunogenicity has led to its use in a large number of clinical applications, such as in controlled-release and targeted drug delivery systems. However, most studies are still only in the in vitro experimental stage and no data are available about the use of HA in place of the traditional macrogol gel (MG) as a vehicle for antibiotic mixtures in REPs [31].

The aim of this study was to evaluate the antibacterial efficacy and depth of action of the novel 3-MIXC compared with the 3-MIX and 2-MIX antibiotic mixtures, vehicled with HA or MG, using confocal laser scanning microscopy (CLSM).

\section{Materials and Methods}

A sample size of 10 per group was calculated with G*Power 3.1.4 (Kiel University, Kiel, Germany) to set the study power at $80 \%$. Seventy-two human single-root teeth, each with an intact crown and fully formed apex, were kept in $0.01 \% \mathrm{NaOCl}$ solution after extractions for periodontal disease. The soft tissues, bone fragments and cementum were removed from the root surface using a hand curette and Sof-lex discs (3M ESPE, Seefeld, Germany). After the access opening, the canal scouting and the initial glide path were performed with a size 10 K-File at the working length (WL) using 
Glyde (Dentsply Sirona, Switzerland) as a lubricating agent. The mechanical glide path was performed with ProGlider (Dentsply Sirona, Switzerland) (tip size $=0.16 \mathrm{~mm}$, taper $=0.02$ up to $0.85 \mathrm{~mm}$ ). Root canal shaping was completed with ProTaper Next X1, X2 and X3 (PTN X3 tip size $=0.30 \mathrm{~mm}$, taper $=0.07 \mathrm{~mm})$. The specimens were irrigated by alternating $5 \%$ sodium hypochlorite $(\mathrm{NaOCl})$ and $10 \%$ ethylenediaminetetraacetic acid (EDTA) to a total of $10 \mathrm{~mL}$ of each solution per specimen. A $4 \mathrm{~mm}$ long root dentin block was horizontally sectioned for each tooth, starting $1 \mathrm{~mm}$ below the cementum-enamel junction, with a $0.6 \mathrm{~mm}$ thick precision diamond saw (Isomet 5000; Buehler Ltd., Lake Bluff, IL) at $1000 \mathrm{rpm}$, under water cooling. Afterwards, the root canals' diameters were standardized to the size of the Gates-Glidden drill no. 4 (1.1 mm in diameter) (Dentsply Sirona, Ballaigues, Switzerland), at $300 \mathrm{rpm}$, under water cooling. All of the dentin blocks were immersed in $5 \% \mathrm{NaOCl}$ and $17 \%$ EDTA, each for $15 \mathrm{~min}$, in an ultrasonic bath, to remove any organic matter and smear layer, then rinsed with sterile water for $10 \mathrm{~min}$. The previous procedure was also performed to minimize the fluorescence from the dentin. The roots were inspected under a microscope to verify the canal cleanliness and the absence of cracks. The specimens were stored in saline prior to their packaging and sterilization in an autoclave. The sterilized specimens were then placed in a multi-well test plate under a laminar flow biohazard cabinet (CLANLAF-VFR 1206, Racine, WI, USA). The root canals were infected with an overnight culture of Enterococcus faecalis ATCC 29212 at a turbidity of $3 \times 10^{7}$ colony forming units $/ \mathrm{mL}$, as confirmed by the colony counts in triplicate, in Brain Heart Infusion broth (BHI; Oxoid, Milan, Italy). E. faecalis ATCC 29212 was chosen for this study after a careful review of the literature, which revealed that this bacterium has multiple properties that lead to its key role as an endodontic pathogen [32]. The samples were incubated under aerobic conditions at $37^{\circ} \mathrm{C}$ for 3 weeks and were centrifugated to allow for the penetration of E. faecalis into the dentin tubules. The broth was replaced every 4 days [33] and the culture purity was checked regularly.

After 3 weeks, the specimens were randomly assigned to 3 experimental groups (each group $\mathrm{N}=20)$, positive $(\mathrm{N}=6)$ and negative $(\mathrm{N}=6)$ control groups. The specimens in the first experimental group were exposed to the 3-MIX antibiotic paste (ciprofloxacin $2 \mu \mathrm{g} / \mathrm{mL}$, metronidazole $8 \mu \mathrm{g} / \mathrm{mL}$ and minocycline $4 \mu \mathrm{g} / \mathrm{mL}$ ). Those in the second experimental group were exposed to the 3-MIXC paste (ciprofloxacin $2 \mu \mathrm{g} / \mathrm{mL}$, metronidazole $8 \mu \mathrm{g} / \mathrm{mL}$ and clarithromycin $2 \mu \mathrm{g} / \mathrm{mL}$ ), and the specimens in the third group were exposed to the 2-MIX (ciprofloxacin $2 \mu \mathrm{g} / \mathrm{mL}$ and metronidazole $8 \mu \mathrm{g} / \mathrm{mL}$ ) antibiotic paste. The different antibiotic formulations were mixed with MG or HA as vehicles, dividing each experimental group in two sub-groups $(\mathrm{N}=10)$. Experimental samples were exposed to antibiotics for three weeks [11,24], with fresh broth every 4 days. Twelve specimens served as controls: six teeth were autoclaved and used as negative controls, while 6 teeth did, after bacterial incubation, not receive canal disinfection, were inoculated with HA or MG and were used as positive controls. These samples were used to assess the biofilm formation through the CLSM examination (Figure 1). 


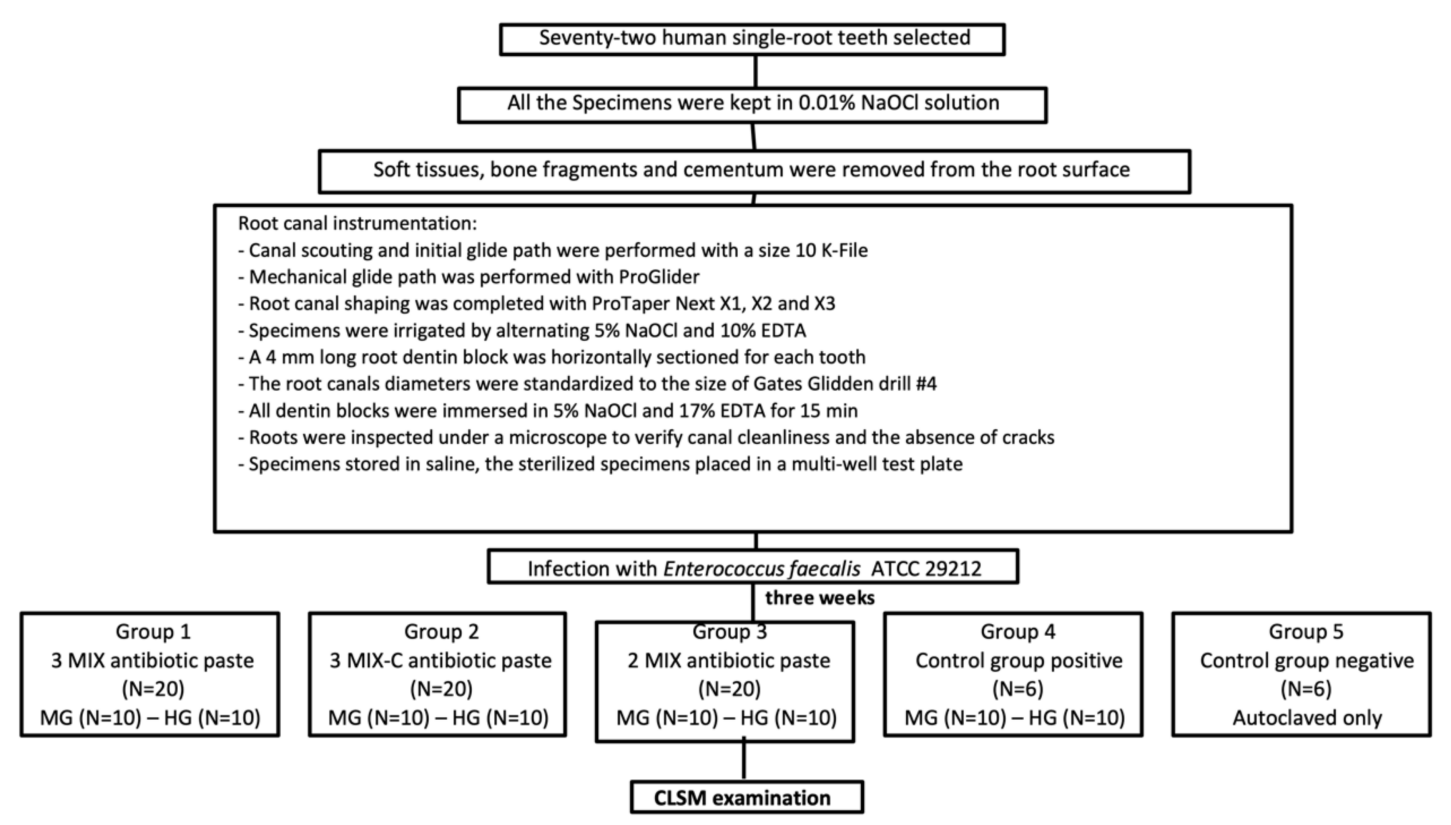

Figure 1. Flow diagram of the study design. 2-MIX, ciprofloxacin and metronidazole; 3-MIX ciprofloxacin, metronidazole and minocycline; 3-MIXC, ciprofloxacin, metronidazole and clarithromycin; HA, hyaluronic acid; MG, macrogol gel.

After the exposure, the specimens were rinsed with sterile saline solution to remove the antibiotic paste from the root canal and each cylindrical dentin block was fractured into 2 identical semi-cylindrical halves. The fracture was performed by making a longitudinal groove on the external root surface with a thin bur (Dentsply Sirona) and then by using a blade with a stable support, in order to ensure a very thin and flat surface. The outer surfaces of the semi-cylindrical halves were ground with 600-grit silicon carbide paper (ARC Abrasives Inc, Troy, OH) to achieve a standard thickness of $2 \mathrm{~mm}$ and to remove the root surface cementum. The dentin specimens were then shaped with a water-cooled low-speed headpiece and a fine carbide bur at $300 \mathrm{rpm}$ to fit each specimen into the inner wall of a filter tube with a $0.45 \mathrm{~mm}$ pore size (Pall Corporation, Ann Arbor, MI, USA). The refined specimens measured approximately $4 \times 4 \times 2 \mathrm{~mm}$. The LIVE/DEAD (L/D) BacLight Bacteria Viability Kit (TermoFisher Scientific, Waltham, MA, USA) was used to detect viable and dead bacteria using a 1:1 ratio of SYTO 9 (20/1) and propidium iodine (PI, 120/1) [34]. After staining with the L/D viability test solution, the specimens were positioned in $100 \mu \mathrm{L}$ of saline solution in a multi-well and stored within a microscopy chamber in a dark room. The specimens were washed in sterile water for $1 \mathrm{~min}$ and were then vertically fractured-through the root canal-into 2 halves, as described above, to expose fresh and flat surfaces of longitudinally visible dentin canals for CLSM examination. The imaging was performed using a laser scanning confocal system (Fluoview 200, Olympus America, Melville, NY, USA), with the specimens mounted on an inverted microscope (model IX70, Olympus Optical Co. GMBH, Hamburg, Germany), illuminated by a krypton/argon laser (488 nm). Emission wavelengths of 505-550 nm (green, SYTO 9) and 650-750 nm (red, PI) were utilized to visualize SYTO 9 (live bacteria) and PI (dead bacteria), respectively. The images were taken using a 20× objective with an additional zoom of $2 \times$ and processed and analyzed with ImageJ software (NIH, Bethesda, MD, USA). Six samples were analyzed as positive controls to assess the formation of a bacterial biofilm and the bacterial viability (\%) was calculated from the CLSM images. For the tested samples, the mean antibiotic depth of action was calculated from 10 separate measurements for each single image, adjusted for the red color channel. Data were recorded and differences were analyzed with one-way ANOVA and a post-hoc Bonferroni test $(p<0.05)$. The ratio of red fluorescence to green-and-red fluorescence (indicating the proportion of dead cells for each group) was calculated from merged images and three-dimensional reconstructions. This measurement was considered to be a surrogate marker of bactericidal efficacy. 
The Kolmogorov-Smirnov test for normality was used to analyze the data distribution. The data were collected and the differences among the groups were analyzed by using Kruskall-Wallis and Dunn's post-hoc tests $(p<0.05)$.

\section{Results}

The penetration by E. faecalis from the side of the root canal into the dentinal tubules of the specimens was verified with CLSM. A homogeneous infection, with a minimum depth of $300 \mu \mathrm{m}$, was reached in all of the specimens. The negative control group showed no bacterial contamination. The mean depth of action and the red fluorescence ratios for each group and sub-group are reported in Table 1 and Figure 2. The 3-MIX and 3-MIXC antibiotic pastes exhibited similar depths of action, which were slightly higher than that of 2-MIX, but the differences were not statistically significant $(p>0.05)$. Moreover, the HA or MG vehicles did not significantly influence the depth of action in any tested group $(p>0.05)$. The mean ratios of red fluorescence to green-and-red fluorescence were similar between the 3-MIX and 3-MIXC groups, and both were statistically higher than those of the 2-MIX group $(p=0.014)$. Each antibiotic mixture demonstrated a higher bactericidal efficacy if conveyed with HA compared to MG (3-MIX, $p=0.019$; 3-MIXC, $p=0.013$ and 2-MIX, $p=0.0125$ ). The images from the control groups are reported in Figure 3.

Table 1. The mean depth of action and the mean proportion of dead cell volume for each tested group and sub-group (3-MIX (ciprofloxacin, metronidazole and minocycline); 3-MIXC (ciprofloxacin, metronidazole and clarithromycin); 2-MIX (ciprofloxacin and metronidazole); hyaluronic acid (HA) and macrogol (MG)). The different superscript letters indicate the statistically significant differences between the groups $(p<0.05)$. Among the mean proportion of dead cell volume, 2-MIX groups showed different results when compared with the other groups and the presence of HA significantly influenced all of the groups.

\begin{tabular}{ccc}
\hline & Mean Depth of Action $(\mu \mathrm{m})$ & $\begin{array}{c}\text { Mean Proportion of Dead Cells } \\
\text { Volume (Red Fluorescence Ratio) }\end{array}$ \\
\hline 3-MIX hyaluronic acid (HA) (N = 10) & $290 \pm 58.5^{\text {aa }}$ & $0.89 \pm 0.01^{\mathrm{aa}}$ \\
3-MIX macrogol gel (MG) (N = 10) & $230.7 \pm 39.1^{\text {aa }}$ & $0.70 \pm 0.02^{\mathrm{ab}}$ \\
3-MIXC HA (N = 10) & $268.2 \pm 30.2^{\text {aa }}$ & $0.85 \pm 0.02^{\mathrm{aa}}$ \\
3-MIXC MG (N = 10) & $246 \pm 48.1^{\text {aa }}$ a & $0.71 \pm 0.01^{\mathrm{ab}}$ \\
2-MIX HA (N = 10) & $202.3 \pm 38.5^{\text {aa }}$ & $0.69 \pm 0.01^{\mathrm{ba}}$ \\
2-MIX MG (N = 10) & $168.8 \pm 31^{\text {aa }}$ & $0.60 \pm 0.01^{\mathrm{bb}}$ \\
Positive controls HA (N = 3) & $0.5 \pm 0^{\mathrm{bb}}$ & $0.01 \pm 0^{\mathrm{cc}}$ \\
Positive controls MG (N = 3) & $0.5 \pm 0^{\mathrm{bb}}$ & $0.01 \pm 0^{\mathrm{cc}}$ \\
Negative controls (N = 6) & $\mathrm{Nd}$ & $\mathrm{Nd}$ \\
\hline
\end{tabular}

Superscript letters: the different letters show the statistically significant differences among the groups $(p<0.05)$. The first superscript letter refers to the comparison between the antibiotic pastes, while the second one refers to the type of vehicle tested. Nd: data not determined. 

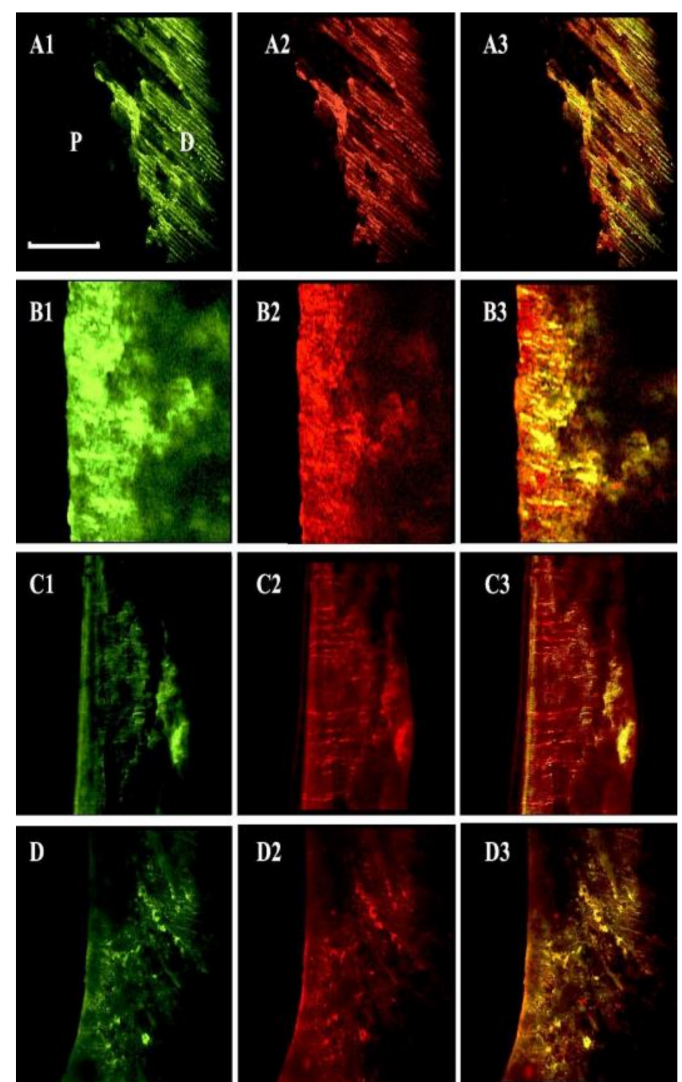

D2
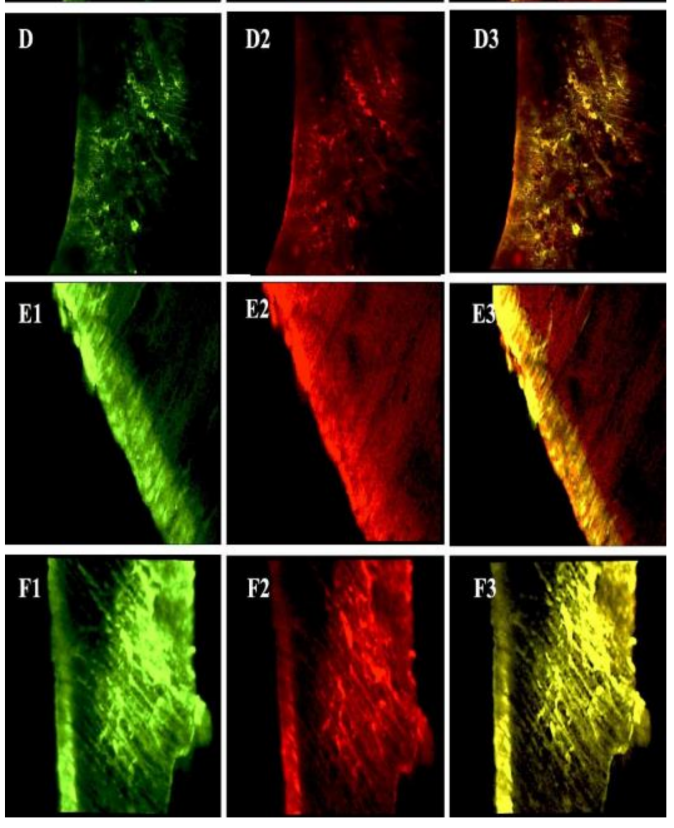

Figure 2. The confocal laser scanning microscopy of the Enterococcus faecalis-infected dentinal tubules, treated with the different antibacterial pastes, after viability staining. Two-dimensional images of the green channel (A1-F1); two-dimensional images of the red channel (A2-F2); two-dimensional images of the composite reconstruction (A3-F3). 3-MIX with HA (A1-A3); 3-MIX with MG (B1-B3); 3-MIXC with HA (C1-C3); 3-MIXC with MG (D1-D3); 2MIX with HA (E1-E3); 2-MIX with MG (F1-F3). 2MIX: ciprofloxacin and metronidazole; 3-MIX: ciprofloxacin, metronidazole and minocycline; 3-MIXC: ciprofloxacin, metronidazole and clarithromycin; hyaluronic acid (HA); macrogol gel (MG); dentin (D); pulpal side $(\mathrm{P})$. The scale line length is $300 \mu \mathrm{m}$. 


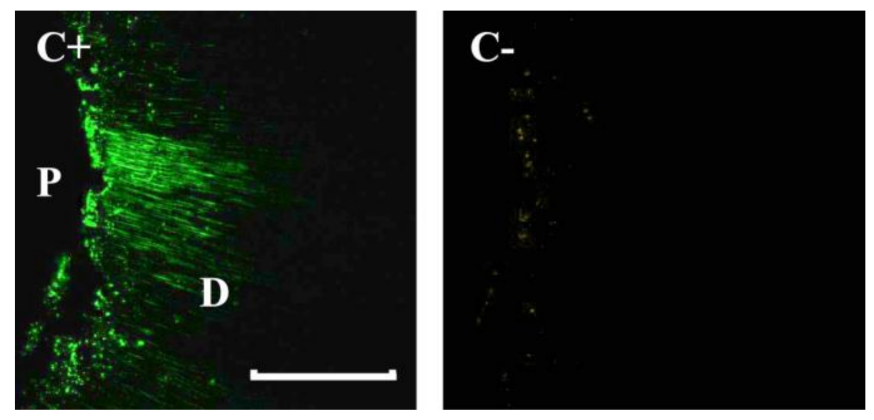

Figure 3. Confocal laser scanning microscopy composite reconstructions of dentinal tubules of positive $(\mathbf{C}+)$ and negative (C-) controls. D, dentin; $\mathbf{P}$, pulpal side. The scale length is $300 \mu \mathrm{m}$.

\section{Discussion}

REPs aim to regenerate the functional pulp tissue in necrotic immature teeth [6]. Although the histologic findings following REPs are variable, the complete elimination of bacteria from the canal system is mandatory to promote the ingrowth of any vital tissue $[3,8,9]$. A remarkable number of microorganisms are able to invade the root canal space, forming a biofilm and infiltrating the dentinal walls [35]. Therefore, REPs require a high-level, wide-spectrum disinfection, deep into the dentinal tubules, that does not disrupt the remaining dentin, or negatively affect stem cell viability $[12,13,17,24]$. The American Association of Endodontists' Regenerative Committee has established a recent protocol which includes the use of either calcium hydroxide or DAP and TAP [11]. Therefore, the use of effective antibiotic mixtures is a current subject of interest [36]. Due to the complexity of infection, a combination of different antibiotics is recommended to overcome root canal microbial flora [14,15,37]. Previous studies have assessed the antibacterial efficacy of the 3-MIX deep in the dentinal tubules of immature teeth $[12,37,38]$. One negative characteristic of the 3-MIX is the persistent tooth discoloration that may occur due to the presence of minocycline [19,23]. However, root staining was reported even when minocycline was replaced with doxycycline [18]. A further drawback is TAP toxicity, with concentrations above $1 \mathrm{mg} / \mathrm{mL}$ deemed to be toxic for stem cells from the apical papilla (SCAP) in vitro [24]. Previous studies have suggested that TAP toxicity may occur at even lower concentrations [38]. Based on current data, regenerative protocols using DAP or TAP at a concentration of $0.1 \mathrm{mg} / \mathrm{mL}$ are recommended [11], despite their variable efficacy [24,38-41]. A study from Mandras et al. demonstrated that TAP-containing clarithromycin showed high efficacy against cultures of E. faecalis, without any staining effect in vitro [26]. The objective of the cited study was to evaluate the incidence of potential discoloration of 3-MIXC and 3-MICF (a mixture of ciprofloxacin, metronidazole and fosfomycine) as possible alternatives to minocycline-based TAPs. The root canals were randomly divided into five groups and brought into contact with the different antibiotic mixtures for 3 weeks. Within the study conditions, the discoloration effect was avoided with the use of clarithromycin instead of minocycline in TAPs and a dark green-brown shade appeared only for the 3-MIX samples containing minocycline. In the other groups and in the control group, the root stain remained unchanged. Moreover, clarithromycin showed a higher ability to kill the endodontic pathogens in vitro compared to fosfomycine. Clarithromycin is an advanced generation macrolide with a wide spectrum of activity and excellent inflammatory-dependent activity, both intra and extracellular [27-29]. Moreover, it has been shown to exhibit anti-inflammatory properties and the associated side effects are typically mild [26,42]. In the present study, the root samples were infected with E. faecalis, a Gram-positive facultative anaerobe, in order to test the antibacterial efficacy and depth of action of the antibiotic mixtures on dentin.

As suggested by previous epidemiological studies, E. faecalis is commonly present in persistent endodontic infections, with a prevalence of $24 \%$ to $77 \%$. It is able to compete with other microorganisms, invade the dentinal tubules and resist nutritional deprivation. It is believed to be a major cause for the failure of root canal treatment. It can penetrate the dentinal tubules and it is able to create biofilm [35]. 
E. faecalis develops strong resistance to extremely harsh environments, including a highly alkaline $\mathrm{pH}$, nutritional deficiency and many current clinical intra-canal medications, and it is resistant to most root canal disinfectants $[35,43]$. Therefore, the continuous study of E. faecalis and its elimination from the dental apparatus can define the future of the endodontic specialty and this resistance has made the control of E. faecalis infection a great challenge for dentists worldwide.

Moreover, it is widely used in endodontic disinfecting agents in vitro testing, as well as in the only study that has tested 3MIX-C in vitro $[26,44,45]$. The dentin infection model was selected due to the need to assess the antibacterial effect on a heavy infection in the dentin tubules being more related to clinical reality [33]. The CLSM analysis, combined with viability staining, was proposed as a reliable method to assess the formation of a bacterial biofilm in the dentinal tubules after incubation [46]. Moreover, the quantitative analysis of bacterial viability after the disinfection was achieved through CLSM, which has been previously described as an accurate method to visualize the remaining bacteria in the dentinal tubules [33,34]. The division of the samples with a scalpel on the previously prepared grooves is still proposed to obtain a clear and flat surface without artifacts and debris for the CLSM analysis [46]. Three weeks' aerobic incubation and centrifugation were used to ensure an adequate penetration of bacteria into the dentinal tubules $[24,33,34]$. The mean depth of action is a surrogate marker of the penetration ability of the tested antibiotic mixture into the dentinal tubules. For all groups, this parameter was comparable with existing reports in the literature [47]. The ratio of red fluorescence was slightly higher for the TAP groups compared with the DAP specimens, probably due to the higher antimicrobial action of TAPs $[24,26]$. These values cannot be easily compared to previous studies due to the variety of infection protocols and solutions that were tested, which may influence the penetration ability and depth of action [24,33]. Moreover, the absolute ratio of red fluorescence could be influenced by the threshold scale used for the green channel, due to the slight green fluorescence of the natural dentin structure observed with CLSM. However, the positive control specimens showed bright fluorescent staining, whereas negative samples did not stain with either dye. Interestingly, enhanced antimicrobial effects were reported when the antibiotic mixtures were conveyed with HA, possibly due to its well-described bacteriostatic effect [30,48,49], even if MG also displayed slight antibacterial properties [50]. HA displays unique structural and physiological functions within tissues, including extracellular and intracellular interactions, and growth factor modulation [51]. A recent study described a positive correlation between the HA scaffold and SCAP survival during REPs [52]. Moreover, HA-conveyed DAPs and TAPs appear more fluid and applicable inside the root canal. In conclusion, within the limitations of this in vitro study, the 3-MIXC mixed with the HA appeared to be a possible alternative for root canal disinfection during REPs. Both the antibacterial efficacy and the depth of action of the 3-MIXC are comparable to the traditional TAPs used for dental pulp regeneration, without the risk of tooth discoloration, and the use of HA to convey the TAPs could enhance the antibacterial properties.

Author Contributions: Conceptualization, D.P. and A.C.; Methodology, N.M., M.A., J.R., P.C., A.L., D.P. and S.A.; Software and Validation, M.A. and J.R.; Investigation, N.M., M.A., J.R., D.P. and G.B.; Resources, M.A., D.P., E.G. and E.B; Writing-Original Draft Preparation, N.M., M.A. and J.R.; Review \& Editing, N.M., M.A., J.R, S.A. and A.C.; Visualization, N.M., M.A., J.R., P.C., A.L., D.P., E.G., and G.B.; Supervision, S.A., A.C. and E.B. All authors have read and agreed to the published version of the manuscript.

Funding: This research did not receive any specific grant from funding agencies in the public, commercial, or not-for-profit sectors.

Conflicts of Interest: The authors declare no conflict of interest.

\section{References}

1. Alobaid, A.S.; Cortes, L.M.; Lo, J.; Nguyen, T.T.; Albert, J.; Abu-Melha, A.S.; Lin, L.M.; Gibbs, J.L. Radiographic and clinical outcomes of the treatment of immature permanent teeth by revascularization or apexification: A pilot retrospective cohort study. J. Endod. 2014, 40, 1063-1070. [CrossRef] [PubMed] 
2. Trope, M. Treatment of immature teeth with non-vital pulps and apical periodontitis. Endod. Top. 2006, 14, 51-59. [CrossRef]

3. Jeeruphan, T.; Jantarat, J.; Yanpiset, K.; Suwannapan, L.; Khewsawai, P.; Hargreaves, K.M. Mahidol study 1: Comparison of radio-graphic and survival outcomes of immature teeth treated with either regenerative endodontic or apexification methods: A retrospective study. J. Endod. 2012, 38, 1330-1336. [CrossRef]

4. Mente, J.; Leo, M.; Panagidis, D.; Ohle, M.; Schneider, S.; Bermejo, J.L.; Pfefferle, T. Treatment Outcome of Mineral Trioxide Aggregate in Open Apex Teeth. J. Endod. 2013, 39, 20-26. [CrossRef] [PubMed]

5. Chala, S.; Abouqal, R.; Rida, S. Apexification of immature teeth with calcium hydroxide or mineral trioxide aggregate: Systematic review and meta-analysis. Oral Surg. Oral Med. Oral Pathol. Oral Radiol. Endodontol. 2011, 112, e36-e42. [CrossRef]

6. American Association of Endodontists (AAE). Colleagues for Excellence. Available online: https://www.aae.org/uploadedfiles/publications_and_research/endodontics_colleagues_for_excellence_ newsletter/ecfespring2013.pdf (accessed on 13 April 2018).

7. Diogenes, A.; Henry, M.A.; Teixeira, F.B.; Hargreaves, K.M. An update on clinical regenerative endodontics. Endod. Top. 2013, 28, 2-23. [CrossRef]

8. Kontakiotis, E.G.; Filippatos, C.G.; Tzanetakis, G.N.; Agrafioti, A. Regenerative Endodontic Therapy: A Data Analysis of Clinical Protocols. J. Endod. 2015, 41, 146-154. [CrossRef]

9. Law, A.S. Considerations for Regeneration Procedures. J. Endod. 2013, 39, S44-S56. [CrossRef]

10. Nagy, M.M.; Tawfik, H.E.; Hashem, A.A.R.; Abu-Seida, A.M. Regenerative Potential of Immature Permanent Teeth with Necrotic Pulps after Different Regenerative Protocols. J. Endod. 2014, 40, 192-198. [CrossRef]

11. American Association of Endodontists (AAE). Clinical Considerations for a Regenerative Procedure. Available online: https://f3f142zs0k2w1kg84k5p9i1o-wpengine.netdna-ssl.com/specialty/wpcontent/uploads/sites/2/ 2018/06/ConsiderationsForRegEndo_AsOfApril2018.pdf (accessed on 13 April 2018).

12. Ding, R.Y.; Cheung, G.S.P.; Chen, J.; Yin, X.Z.; Wang, Q.Q.; Zhang, C.F. Pulp Revascularization of Immature Teeth with Apical Periodontitis: A Clinical Study. J. Endod. 2009, 35, 745-749. [CrossRef]

13. Fouad, A.F.; Verma, P. Healing after Regenerative Procedures with and without Pulpal Infection. J. Endod. 2014, 40, 58-64. [CrossRef] [PubMed]

14. Hoshino, E.; Kurihara-Ando, N.; Sato, I.; Uematsu, H.; Sato, M.; Kota, K.; Iwaku, M. In-vitro antibacterial susceptibility of bacteria taken from infected root dentine to a mixture of ciprofloxacin, metronidazole and minocycline. Int. Endod. J. 1996, 29, 125-130. [CrossRef] [PubMed]

15. Sato, I.; Kota, K.; Iwaku, M.; Hoshino, E.; Ando-Kurihara, N. Sterilization of infected root-canal dentine by topical application of a mixture of ciprofloxacin, metronidazole and minocycline in situ. Int. Endod. J. 1996, 29, 118-124. [CrossRef] [PubMed]

16. Akcay, M.; Arslan, H.; Yaşa, B.; Kavrık, F.; Yasa, E.; Kavrik, F. Spectrophotometric Analysis of Crown Discoloration Induced by Various Antibiotic Pastes Used in Revascularization. J. Endod. 2014, 40, 845-848. [CrossRef] [PubMed]

17. Montero-Miralles, P.; Martín-González, J.; Alonso-Ezpeleta, O.; Jiménez-Sánchez, M.; Velasco-Ortega, E.; Segura-Egea, J.J. Effectiveness and clinical implications of the use of topical antibiotics in regenerative endodontic procedures: A review. Int. Endod. J. 2018, 51, 981-988. [CrossRef]

18. Porter, M.L.; Münchow, E.A.; Albuquerque, M.T.; Spolnik, K.J.; Hara, A.T.; Bottino, M.C. Effects of novel 3-dimensional antibiotic-containing electrospun scaffolds on dentin discoloration. J. Endod. 2016, 42, 106-112. [CrossRef]

19. Kim, J.H.; Kim, Y.; Shin, S.J.; Park, J.W.; Jung, I.Y. Tooth Discoloration of Immature Permanent Incisor Associated with Triple Antibiotic Therapy: A Case Report. J. Endod. 2010, 36, 1086-1091. [CrossRef]

20. Reynolds, K.; Johnson, J.D.; Cohenca, N. Pulp revascularization of necrotic bilateral bicuspids using a modified novel technique to eliminate potential coronal discolouration: A case report. Int. Endod. J. 2009, 42, 84-92. [CrossRef]

21. Galler, K.M.; Krastl, G.; Simon, S.; Van Gorp, G.; Meschi, N.; Vahedi, B.; Lambrechts, P. European Society of Endodontology position statement: Revitalization procedures. Int. Endod. J. 2016, 49, 717-723. [CrossRef]

22. Andreasen, J.O.; Munksgaard, E.C.; Bakland, L.K. Comparison of fracture resistance in root canals of immature sheep teeth after filling with calcium hydroxide or MTA. Dent. Traumatol. 2006, 22, $154-156$. [CrossRef] 
23. Kahler, B.; Rossi-Fedele, G. A Review of Tooth Discoloration after Regenerative Endodontic Therapy. J. Endod. 2016, 42, 563-569. [CrossRef]

24. Latham, J.; Fong, H.; Jewett, A.; Johnson, J.D.; Paranjpe, A. Disinfection Efficacy of Current Regenerative Endodontic Protocols in Simulated Necrotic Immature Permanent Teeth. J. Endod. 2016, 42, 1218-1225. [CrossRef] [PubMed]

25. Jacobs, J.C.; Troxel, A.; Ehrlich, Y.; Spolnik, K.; Bringas, J.S.; Gregory, R.L.; Yassen, G.H. Antibacterial Effects of Antimicrobials Used in Regenerative Endodontics against Biofilm Bacteria Obtained from Mature and Immature Teeth with Necrotic Pulps. J. Endod. 2017, 43, 575-579. [CrossRef] [PubMed]

26. Mandras, N.; Roana, J.; Allizond, V.; Pasqualini, D.; Crosasso, P.; Burlando, M.; Banche, G.; Denisova, T.; Berutti, E.; Cuffini, A. Antibacterial Efficacy and Drug-Induced Tooth Discolouration of Antibiotic Combinations for Endodontic Regenerative Procedures. Int. J. Immunopathol. Pharmacol. 2013, 26, 557-563. [CrossRef]

27. Amsden, G.W. Advanced-generation macrolides: Tissue-directed antibiotics. Int. J. Antimicrob. Agents 2001, 18, 11-15. [CrossRef]

28. Banche, G.; Allizond, V.; Mandras, N.; Tullio, V.; Cuffini, A.M. Host immune modulation by antimicrobial drugs: Current knowledge and implications for antimicrobial chemotherapy. Curr. Opin. Pharmacol. 2014, 18, 159-166. [CrossRef] [PubMed]

29. Cuffini, A.M.; Tullio, V.; Mandras, N.; Roana, J.; Scalas, D.; Banche, G.; Carlone, N.A. Clarithromycin mediated the expression of polymorphonuclear granulocyte response against streptococcus pneumoniae strains with different patterns of susceptibility and resistance to penicillin and clarithromycin. Int. J. Tissue React. 2002, 24, 37-44.

30. Johannsen, A.; Tellefsen, M.; Wikesjö, U.; Johannsen, G. Local delivery of hyaluronan as an adjunct to scaling and root planning in the treatment of chronic periodontitis. J. Periodontol. 2009, 80, 1493-1497. [CrossRef]

31. Huang, G.; Huang, H. Application of hyaluronic acid as carriers in drug delivery. Drug Deliv. 2018, 25, 766-772. [CrossRef] [PubMed]

32. Zhang, C.J.; Du, J.R.; Peng, Z.X. Correlation between Enterococcus faecalis and Persistent Intraradicular Infection Compared with Primary Intraradicular Infection: A Systematic Review. J. Endod. 2015, 41, 1207-1213. [CrossRef]

33. Ma, J.Z.; Wang, Z.J.; Shen, Y.; Haapasalo, M. A New Noninvasive Model to Study the Effectiveness of Dentin Disinfection by Using Confocal Laser Scanning Microscopy. J. Endod. 2011, 37, 1380-1385. [CrossRef] [PubMed]

34. Parmar, D.; Hauman, C.H.J.; Leichter, J.W.; McNaughton, A.; Tompkins, G.R. Bacterial localization and viability assessment in human ex vivo dentinal tubules by fluorescence confocal laser scanning microscopy. Int. Endod. J. 2011, 44, 644-651. [CrossRef] [PubMed]

35. Fouad, A. The microbial challenge to pulp regeneration. Adv. Dent. Res. 2011, 23, 285-289. [CrossRef] [PubMed]

36. Kim, S.G.; Malek, M.; Sigurdsson, A.; Lin, L.M.; Kahler, B. Regenerative endodontics: A comprehensive review. Int. Endod. J. 2018, 51, 1367-1388. [CrossRef]

37. Iii, W.W.; Teixeira, F.; Levin, L.; Sigurdsson, A.; Trope, M. Disinfection of Immature Teeth with a Triple Antibiotic Paste. J. Endod. 2005, 31, 439-443.

38. Chuensombat, S.; Khemaleelakul, S.; Chattipakorn, S.; Srisuwan, T. Cytotoxic Effects and Antibacterial Efficacy of a 3-Antibiotic Combination: An In Vitro Study. J. Endod. 2013, 39, 813-819. [CrossRef]

39. Ruparel, N.B.; Teixeira, F.B.; Ferraz, C.C.; Diogenes, A. Direct Effect of Intracanal Medicaments on Survival of Stem Cells of the Apical Papilla. J. Endod. 2012, 38, 1372-1375. [CrossRef]

40. Diogenes, A.R.; Ruparel, N.B.; Teixeira, F.B.; Hargreaves, K.M. Translational Science in Disinfection for Regenerative Endodontics. J. Endod. 2014, 40, 52-57. [CrossRef]

41. Kitikuson, P.; Srisuwan, T. Attachment Ability of Human Apical Papilla Cells to Root Dentin Surfaces Treated with Either 3Mix or Calcium Hydroxide. J. Endod. 2016, 42, 89-94. [CrossRef]

42. Burrell, R.C.; Walters, J.D. Distribution of systemic clarithromycin to gingiva. J. Periodontol. 2008, 79, 1712-1718. [CrossRef]

43. Swimberghe, R.C.D.; Coenye, T.; De Moor, R.J.G.; Meire, M.A. Biofilm model systems for root canal disinfection: A literature review. Int. Endod. J. 2019, 52, 604-628. [CrossRef] [PubMed] 
44. Mandras, N.; Allizond, V.; Bianco, A.; Banche, G.; Roana, J.; Piazza, L.; Viale, P.; Cuffini, A.M. Antimicrobial efficacy of cryotreatment against Enterococcus faecalis in root canals. Lett. Appl. Microbiol. 2013, 56, 95-98. [CrossRef] [PubMed]

45. Halkai, K.R.; Mudda, J.A.; Shivanna, V.; Rathod, V.; Halkai, R. Antibacterial Efficacy of Biosynthesized Silver Nanoparticles against Enterococcus faecalis Biofilm: An in vitro Study. Contemp. Clin. Dent. 2018, 9, $237-241$. [CrossRef] [PubMed]

46. Kishen, A.; Shrestha, A.; Del Carpio-Perochena, A. Validation of Biofilm Assays to Assess Antibiofilm Efficacy in Instrumented Root Canals after Syringe Irrigation and Sonic Agitation. J. Endod. 2018, 44, 292-298. [CrossRef] [PubMed]

47. Berkhoff, J.A.; Chen, P.B.; Teixeira, F.B.; Diogenes, A. Evaluation of Triple Antibiotic Paste Removal by Different Irrigation Procedures. J. Endod. 2014, 40, 1172-1177. [CrossRef]

48. Pirnazar, P.; Wolinsky, L.; Nachnani, S.; Haake, S.; Pilloni, A.; Bernard, G.W. Bacteriostatic Effects of Hyaluronic Acid. J. Periodontol. 1999, 70, 370-374. [CrossRef]

49. Romanò, C.; De Vecchi, E.; Bortolin, M.; Morelli, I.; Drago, L. Hyaluronic Acid and Its Composites as a Local Antimicrobial/Antiadhesive Barrier. J. Bone Jt. Infect. 2017, 2, 63-72. [CrossRef]

50. Nalawade, T.M.; Sogi, S.H.P.; Bhat, K. Bactericidal activity of propylene glycol, glycerine, polyethylene glycol 400, and polyethylene glycol 1000 against selected microorganisms. J. Int. Soc. Prev. Community Dent. 2015, 5, 114-119. [CrossRef]

51. Xu, Y.; Höfling, K.; Fimmers, R.; Frentzen, M.; Jervøe-Storm, P.M. Clinical and microbiological effects of topical sub gingival application of hyaluronic acid gel adjunctive to scaling and root planning in the treatment of chronic periodontitis. J. Periodontol. 2004, 75, 1114-1118. [CrossRef]

52. Chrepa, V.; Austah, O.; Diogenes, A. Evaluation of a Commercially Available Hyaluronic Acid Hydrogel (Restylane) as Injectable Scaffold for Dental Pulp Regeneration: An In Vitro Evaluation. J. Endod. 2017, 43, 257-262. [CrossRef]

(C) 2020 by the authors. Licensee MDPI, Basel, Switzerland. This article is an open access article distributed under the terms and conditions of the Creative Commons Attribution (CC BY) license (http://creativecommons.org/licenses/by/4.0/). 